\title{
GAMBARAN STRESS PADA SISWA SMP-SMA DI SUMATERA BARAT: STUDI DESKRIPTIF
}

\author{
Meria Susanti ${ }^{1}$, Izzanil Hidayati ${ }^{2}$, Nila Anggreiny ${ }^{3}$, and Yantri Maputra ${ }^{4}$ \\ Email: meriasusanti@med.unand.ac.id \\ 1,2,3) Prodi Psikologi Fakultas Kedokteran, Universitas Andalas
}

\begin{abstract}
The Covid-19 pandemic has brought a huge change to today's life. The rapid spread of the process made the government make various efforts to overcome this. One of them is by limiting activities, namely learning activities boldly (school from home). Courageous learning activities make students learn from home. However, in practice many parents and students complain that they are not interested in doing these learning activities. This study aims to determine the impact of distance learning activities (school from home) on the stress of middle and high school students in West Sumatra. The measuring instrument of this research is the Perceived Stress Scale (PSS) by Cohen. The results showed that most junior and senior high school students experienced stress in the moderate category. This is sufficient to indicate that the subject feels that his current life is stressful. Regarding the feelings of subjects with COVID-19, most of the subjects felt worried (26\%), afraid (17\%), and felt shocked (14\%). At the beginning of the pandemic, as many as $94.7 \%$ of students felt that the covid-19 virus was dangerous and only 5.3\% felt it was harmless.
\end{abstract}

Keywords: Stress, Covid-19, teenager

Abstrak. Pandemi Covid-19 memberikan perubahan besar terhadap kehidupan saat ini. Cepatnya proses penyebaran membuat pemerintah melakukan berbagai upaya untuk mengatasi hal tersebut. Salah satunya dengan membatasi kegiatan, yaitu kegiatan belajar secara daring (school from home). Kegiatan pembelajaran daring membuat siswa belajar dari rumah. Namun, pada prakteknya banyak orangtua dan siswa yang mengeluhkan bahwa mereka merasa tidak termotivasi dalam melakukan kegiatan pembelajaran tersebut. Penelitian ini bertujuan untuk mengetahui dampak kegiatan pembelajaran jarak jauh (school from home) terhadap stress siswa SMP dan SMA di Sumatera Barat. Alat ukur penelitian ini menggunakan skala Perceived Stress Scale (PSS) oleh Cohen. Hasil penelitian menunjukkan bahwa sebagian besar siswa SMP dan SMA mengalami stress pada kategori sedang. Hal ini mengindikasikan bahwa subjek merasa kehidupannya saat ini cukup membuat stress. Terkait dengan perasaan subjek dengan covid-19, sebagian besar subjek merasa merasa cemas (26\%), takut (17\%), dan merasa kaget (14\%). Saat awal pandemi, sebanyak $94,7 \%$ siswa merasa bahwa virus covid-19 ini berbahaya dan hanya 5,3\% yang merasa tidak berbahaya.

Kata Kunci: Stress, Covid-19, Remaja 


\section{Pengantar}

Di akhir tahun 2019 dunia dikejutkan dengan adanya kasus penularan virus baru di Cina yang bernama covid-19. Virus tersebut menular dengan sangat cepat. Cepatnya laju penularan virus tersebut membuat WHO menyatakan virus tersebut sebagai pandemic global (Putri, 2020). Berbagai kebijakan dilakukan untuk mengurangi laju penularan virus tersebut. Salah satunya dengan membatasi aktivitas pergerakan. Kebijakan tersebut membuat perubahan besar dalam kehidupan manusia. Kegiatan yang sebelumnya banyak dilakukan di luar rumah, dialihkan untuk sebagian besar dilakukan di dalam rumah. Banyak instansi yang menerapkan kegiatan bekerja dari rumah. Selain itu, proses kegiatan pendidikan pun dipindahkan menjadi kegiatan pembelajaran jarak jauh (PJJ).

Perubahan mendadak dan cukup besar itu membuat berbagai pihak merasakan dampaknya. Salah satu yang merasakan dampak cukup besar adalah dalam bidang pendidikan. Kegiatan pembelajaran yang biasanya dilakukan di sekolah, sekarang harus dilaksanakan di rumah. Hal tersebut tidak hanya mempengaruhi proses belajar yang diberikan guru, tetapi juga dari siswa tidak terkecuali siswa SMP dan SMA.

Para siswa tersebut diharuskan untuk tidak beraktivitas di luar rumah. Masa-masa remaja yang biasanya dihabiskan dengan berkumpul dengan teman-teman, terpaksa tidak dilakukan. Beberapa siswa merasa hal tersebut menjadi sesuatu yang tidak nyaman. Belum lagi kegiatan belajar yang akhirnya dilakukan di rumah. Di tengah ketidakpastian akan situasi dunia akibat covid-19, para remaja juga dipaksa untuk mengurangi aktivitas dengan teman-temannya yang hal tersebut merupakan salah satu kebutuhan penting mereka. Perubahan tersebut bukan tidak mungkin menimbulkan stress bagi remaja. Penelitian ini ingin melihat gambaran stress yang dialami remaja di saat pandemic covid-19 melanda Indonesia.

\section{Landasan Teori}

American Institute of Stress menyatakan bahwa stress adalah kondisi ketidakseimbangan dan atau fisiologis sebagai akibat kesenjangan antara tuntutan dan kemampuan dan atau motivasi individu untuk memenuhi tuntutan tersebut (Abdollahi, Calbring, Khanbani \& Ghafarokhi, 2016). Lebih lanjut, Mimura dan 
Griffiths (2008) menyatakan bahwa stress terjadi ketika adanya ketidakseimbangan antara persepsi individu terhadap tuntutan lingkungan dan kemampuannya dalam menghadapi/ menyelesaikan tuntutan tersebut. Sedangkan Cohen (1983) menyatakan bahwa sesuatu dikatakan sebagai stressor ketika suatu situasi dinilai mengancam dan adanya ketidakmampuan dalam mengatasi hal tersebut. Hal tersebut dapat disimpulkan bahwa pengalaman stress tersebut tergantung penilaian individu terhadap stressor dan kemampuan yang dimilikinya.

Secara umum, stress dapat dikelompokkan ke dalam tiga perseptif, yaitu biologis (respon secara fisiologi terhadap stimulus stressor, lingkungan (berkaitan dengan kejadian yang dialami, dan psikologis (penilaian subjektif terhadap stress (Lazarus, dalam Manzar, dkk, 2019). Stress tersebut dapat memberikan dampak baik terhadap fisik ataupun psikologis seseorang. Taylor (Taylor, 2015) menyatakan bahwa terdapat beberapa karaktersitik suatu kejadian/ situasi dapat menjadi stressor bagi individu, yaitu:

a. Uncontrollable events, yaitu kejadian yang tidak terkontrol. Ketika individu merasa bahwa mereka dapat memprediksi, mengubah, atau mengakhiri kejadian/ perasaan yang tidak menyenangkan yang mereka miliki, mereka mengalami lebih sedikit stress (Thompson, 1981).

b. Ambiguous Events. Ketika stressor merupakan sesuatu yang ambigu/ tidak jelas, individu tidak mampu melakukan sesuatu terkait hal itu. Ketika individu dihadapkan pada situasi stress yang tidak jelas, energi dan waktu individu tersebut akan terkuras untuk berusaha memahami stressor tersebut. Berbeda ketika stressor tersebut merupakan suatu hal yang jelas. Hal itu akan membuat individu bisa fokus menemukan solusi dari permasalahan tersebut dan tidak terjebak hanya dalam upaya memahami masalah.

c. Overload. Individu yang memiliki kelebihan beban kerja (overloaded) biasanya akan mengalami lebih banyak stress dibandingkan dengan individu yang memiliki pekerjaan lebih sedikit.

Masa remaja, merupakan salah satu tahapan perkembangan penting bagi

\section{3 | Psychophedia Jurnal Psikologi Universitas Buana Perjuangan Karawang}


individu. Masa transisi antara masa anak dan masa dewasa membuat berbagai perubahan terjadi dalam diri remaja. Papalia (2007) menyatakan bahwa proses transisi tersebut melibatkan perubahan besar pada aspek fisik, kognitif, dan psikososial individu. Tantangan perkembangan tersebut tidak hanya memberikan peluang untuk pertumbuhan, tetapi juga bisa menjadi penyebab stress bagi remaja (Compas, Hinden \& Gerhardt, 1995 dalam Murray, Byrne, Rieger, 2011). Senada dengan hal tersebut, Dahl \& Gunnar (2009 dalam Mimura \& Griffiths 2008) menyatakan bahwa masa remaja merupakan periode perkembangan yang dikarakteristikkan dengan meningkatnya pengalaman yang menimbulkan stress. Pada masa remaja, kuantitas dan intensitas dari masa transisi tersebut, khususnya terkait kejadian yang tidak terkontrol, bisa memicu stress.

\section{Metode Penelitian}

Skala stress pada penelitian ini menggunakan perceived stress scale (PSS) yang dikonstruksi oleh Cohen (1994). Mimura \& Griffiths (2008) menyatakan bahwa PSS merupakan salah satu instrument yang sering digunakan untuk mengukur persepsi individu terhadap stress. Ada tiga aspek yang diukur dalam skala ini, yaitu:

1. Unpredictable, yaitu seberapa kuat perasaan atau emosi subjek terkait hal yang tidak dapat diprediksi dalam kehidupannya

2. Uncontrollable, yaitu seberapa kuat perasaan individu saat tidak dapat mengontrol segala hal yang terjadi pada dirinya

3. Overloaded, yaitu seberapa kuat perasaan individu saat berada pada situasi penuh dengan beban atau tuntutan

Skala ini memiliki lima pilihan respon, yaitu tidak pernah (1), hampir tidak pernah (2), kadang-kadang (3), cukup sering (4), dan sangat sering (5). Semakin tinggi skornya, maka semakin tinggi level stress yang dirasakan individu.

Proses pengumpulan data dilakukan selama satu bulan. Pengumpulan data dilakukan dengan menggunakan g-form. Peneliti memasukkan kuesioner dan pertanyaan tambahan ke dalam g-form dan menyebarkan link kepada siswa SMP-SMA/ Sederajat di Sumatera Barat. Penyebaran link tersebut dilakukan dengan menggunakan 
media online seperti $W A G$ dan Instagram. Selain itu, peneliti juga meminta bantuan guru-guru yang ada di sekolah untuk menyebarkan kepada pada siswa-siswa. Di bagian awal kuesioner, peneliti menjelaskan informed consent terkait penelitian ini, yaitu

\section{Hasil Penelitian}

1. Gambaran subjek penelitian berdasarkan jenis kelamin mengenai tujuan penelitian, berapa lama waktu pengerjaan serta subjek diberi kebebasan untuk menjadi subjek penelitian ini. Selain itu, juga disediakan reward berupa pulsa sebagai bentuk ucapan terimakasih atas partisipasi subjek dalam penelitian ini.

Berdasarkan data yang diperoleh, subjek penelitian berdasarkan jenis kelamin dapat dilihat melalui tabel berikut:

Tabel 1

Gambaran Subjek Penelitian Berdasarkan Jenis Kelamin

\begin{tabular}{lll}
\hline Jenis Kelamin & Jumlah & Persentase (\%) \\
\hline Laki-laki & 87 orang & $38 \%$ \\
Perempuan & 139 orang & $62 \%$ \\
\hline Total & 226 orang & $100 \%$ \\
\hline
\end{tabular}

Berdasarkan tabel 1 di atas, diketahui bahwa responden yang berjenis kelamin lakilaki berjumlah 87 orang (38\%) dan responden yang berjenis kelamin perempuan berjumlah 139 orang (62\%). Dari sebaran data tersebut,

2. Gambaran subjek penelitian berdasarkan jenjang Pendidikan Berdasarkan data yang diperoleh, subjek penelitian berdasarkan jenjang dapat diketahui pula bahwa responden dalam penelitian lebih banyak berjenis kelamin perempuan daripada laki-laki. 


\section{Tabel 2}

Gambaran Subjek Penelitian Berdasarkan Jenjang Pendidikan

\begin{tabular}{lll}
\hline Jenjang Pendidikan & Jumlah & Persentase (\%) \\
\hline Sekolah Menengah Pertama (SMP) & 58 orang & $26 \%$ \\
Sekolah Menengah Atas (SMA) & 168 orang & $74 \%$ \\
\hline Total & 226 orang & $100 \%$ \\
\hline
\end{tabular}

Berdasarkan tabel 2 di atas, dapat diketahui bahwa responden yang berasal dari jenjang pendidikan Sekolah Menengah Pertama (SMP) berjumlah 58 orang (26\%) dan subjek yang berasal dari jenjang

3. Gambaran subjek penelitian berdasarkan Kabupaten/Kota di Sumatera Barat

Berdasarkan data yang diperoleh, subjek penelitian berdasarkan Kabupaten/Kota di pendidikan Sekolah Menengah Atas (SMA) berjumlah 168 orang (74\%). Dari data tersebut, juga dapat diketahui bahwa subjek dalam penelitian ini lebih banyak siswa SMA daripada siswa SMP.

Sumatera Barat dapat dilihat melalui tabel berikut:

Tabel 3

Gambaran Subjek Penelitian Berdasarkan Kabupaten/Kota di Sumatera Barat

\begin{tabular}{lll}
\hline Kabupaten / Kota & Jumlah & Persentase (\%) \\
\hline Padang & 38 orang & $17 \%$ \\
Pariaman & 13 orang & $6 \%$ \\
Padang Panjang & 75 orang & $33 \%$ \\
Pasaman & 1 orang & $1 \%$ \\
Agam & 89 orang & $39 \%$ \\
Bukittinggi & 10 orang & $4 \%$ \\
\hline Total & 226 orang & $100 \%$ \\
\hline
\end{tabular}

Berdasarkan pada table 3 di atas, dapat diketahui bahwa jumlah responden yang berasal dari kota Padang sebanyak 38 orang (17\%), Pariaman sebanyak 13 orang (6\%), Padang Panjang sebanyak 75 orang (33\%), Pasaman sebanyak 1 orang (1\%), Agam sebanyak 89 orang (39\%), dan Bukit Tinggi sebanyak 10 orang (4\%). Dari data tersebut, dapat diketahui juga bahwa jumlah responden terbanyak ialah dari kabupaten Agam sebanyak 89 orang dan yang paling

\section{6 | Psychophedia Jurnal Psikologi Universitas Buana Perjuangan Karawang}


sedikit ialah responden yang berasal dari Kabupaten Pasaman sebanyak 1 orang.

\section{Tabel 4}

Kategorisasi stress

\begin{tabular}{|c|c|c|c|c|}
\hline Kategorisasi & Rumus & Raw Score & Jumlah & Persentase \\
\hline Tinggi & $(\mathrm{M}+1,0 \mu) \leq \mathrm{X}$ & $36,67 \geq X$ & 20 & $8.8 \%$ \\
\hline Sedang & $\begin{array}{l}(\mathrm{M}-1,0 \mu) \leq \mathrm{X} \\
<(\mathrm{M}+1,0 \mu)\end{array}$ & $\begin{array}{l}23,33 \leq \\
X<36,67\end{array}$ & 194 & $85,8 \%$ \\
\hline Rendah & $\mathrm{X}<(\mathrm{M}-1,0 \mu)$ & $23,33>X$ & 12 & $5,3 \%$ \\
\hline & Total & & 226 & $100 \%$ \\
\hline
\end{tabular}

Keterangan:

M : Mean Teoritis

$\mu \quad$ : Standar Deviasi

X : Skor Total Subjek

\section{Diskusi}

Hasil penelitian menunjukkan bahwa sebagian besar siswa mengalami stress pada kategori sedang. Hal tersebut mengindikasikan bahwa individu merasa kehidupannya saat ini cukup membuat stress. Stres timbul sebagai akibat dari adanya ketidakseimbangan antara persepsi individu terhadap situasi yang menekan dan kemampuannya dalam menghadapi hal tersebut (Cohen, 1997 dalam Mimura \& Griffiths, 2008). Hal tersebut dapat disimpulkan bahwa stress bergantung kepada penilaian individu terhadap suatu stressor dan kemampuannya dalam menghadapi stressor tersebut. Secara umum, stress dapat dikatakan sebagai penilaian individu terhadap suatu kejadian (apakah berbahaya, mengancam, atau menantang), penilaian terhadap sumber daya yang dimiliki, dan respon yang diberikan terhadap kejadian tersebut. Individu menilai suatu kejadian apakah dipersepsikan menjadi sesuatu yang menimbulkan stress atau tidak. Penilaian tersebut dapat dibagi menjadi dua, yaitu primary appraisal dan secondary appraisal (Taylor, 2015). Primary appraisal terjadi ketika individu mencoba memahami suatu kejadian dan apa makna dari kejadian tersebut (Taylor, 2015). Misalnya ketika suatu kejadian diartikan mengancam atau berbahaya. Selanjutnya secondary appraisal, yaitu mengacu kepada apakah individu merasa memiliki sumber yang cukup untuk memenuhi tuntutan lingkungan (Taylor, 2015). Ketika individu merasa bahwa sumber 
daya yang dimilikinya lebih dari cukup untuk mengatasi situasi yang menyulitkan, maka individu tersebut tidak akan merasa begitu stress. Ketika individu merasa bahwa ia memiliki sumber daya yang cukup tetapi harus memiliki usaha yang ekstra untuk mengatasi hal tersebut, maka ia akan merasa cukup stress. Dan ketika ia merasa bahwa sumber daya yang dimiliki tidak cukup untuk mengatasi permasalahan tersebut, maka ia akan berkemungkinan memiliki stress yang cukup besar

Pada hasil penelitian, subjek cukup mempersepsikan kejadian yang dialaminya sebagai sesuatu yang menimbulkan stress. Hal tersebut salah satunya dapat disebabkan oleh terbatasnya aktivitas pertemanan yang dapat dilakukan remaja saat pandemik. Pertemanan memegang peranan penting dalam kehidupan remaja (Santrock, 2012). Masa remaja merupakan masa dimana keinginan untuk menjalin hubungan dengan teman sebaya meningkat (Brown \& Larson, 2009 dalam Ellan \& Dumas, 2020). Papalia, Olds dan Feldman (2007) menyatakan bahwa remaja lebih banyak menghabiskan waktu dengan teman-teman daripada dengan keluarga. Namun, pada masa Pandemik Covid-19, interaksi langsung dengan teman sebaya berkurang, bahkan diawal pandemik menjadi tidak ada. Hal tersebut dapat menjadi stressor tersendiri bagi remaja. Kekhawatiran dalam menjalin hubungan yang dekat dengan teman dan dampak dari isolasi menjadi hal yang penting bagi remaja (Ellis \& Dumas, 2020). Selain itu, remaja juga memiliki kekhawatiran yang sama seperti orang dewasa saat pandemic, yaitu ketakutan akan keadaan diri sendiri dan orang yang disayang, permasalahan keuangan, dan ketidakpastian yang membuat meningkatnya rasa kesepian dan depresi (Wang et a., 2020 dalam Ellis \& Dumas, 2020).

Jika dilihat dari setiap item, maka item yang memiliki mean paling tinggi adalah item yang menanyakan terkait seberapa sering subjek merasa marah/ jengkel ketika terjadi sesuatu yang tidak diharapkan. Hal tersebut mengindikasikan bahwa sebagian besar subjek mengalami perasaan marah saat terjadi sesuatu yang tidak diharapkan. Sedangkan mean yang paling rendah berada pada item seberapa sering subjek merasa dapat mengendalikan hal-hal yang terjadi dalam hidupnya. Hal tersebut mengindikasikan bahwa subjek jarang merasa dapat mengendalikan hal yang terjadi di dalam hidupnya. Hal tersebut dapat 
terjadi karena beberapa bulan tersebut kehidupan subjek berubah drastis. Banyak perubahan yang dirasakan sejak pandemic covid-19 dan memaksa setiap orang untuk beradaptasi. Hal itu bisa menjadi salah satu penyebab subjek merasa kurang dapat mengendalikan hal yang terjadi di dalam hidupnya.

Lebih lanjut, dari hasil pertanyaan terbuka, diketahui bahwa sebagian besar siswa mengalami emosi negatif dengan adanya pandemic covid-19 ini. 25\% siswa merasa cemas saat pertama kali mendengar kasus covid-19 di Indonesia, yang lainnya merasa kaget, takut, resah, gelisah, dan sedih. Walaupun ada juga beberapa yang merasa biasa saja dan tidak peduli. Namun jumlah tersebut hanya sedikit.

Lebih lanjut, Wang et all., (2020) dalam Ellis \& Dumas (2020) menyatakan bahwa dampak covid-19 sudah dirasakan secara luas. Remaja khawatir akan kondisi keuangan keluarga. Hal tersebut juga didapatkan dalam pertanyaan terbuka. Siswa menyatakan bahwa salah satu dampak covid19 adalah menurunnya kondisi keuangan keluarga. Selain itu siswa juga khawatir dirinya atau keluarganya akan tertular virus covid-19. Sebanyak 49,6\% merasa cemas dirinya ataupun keluarganya akan tertular oleh virus tersebut. Lebih lanjut, remaja yang lebih sering menonton ataupun membaca berita terkait covid-19 dilaporkan memiliki stress yang lebih besar (Ellis \& Dumas, 2020).

\section{Kesimpulan}

Dari hasil penelitian diketahui bahwa sebagian besar siswa SMP-SMA di Sumatera Barat berada pada kategori stress sedang. Hal tersebut menunjukkan bahwa sebagian besar siswa SMP-SMA merasa bahwa kondisi pandemic membuat mereka merasa cukup stress. Terkait dengan covid-19 sendiri, sebagian besar siswa SMP-SMA merasa bahwa virus tersebut berbahaya. Mereka menganggap virus itu berbahaya karena penularan dan penyebaran virus tersebut $(35,3 \%)$ dan efek kematian yang ditimbulkan virus tersebut $(33,5 \%)$. Sedangkan dampak terbesar yang dirasakan pada siswa SMPSMA akibat pandemic covid-19 ini adalah berubah nya sistem belajar menjadi daring (35\%), berefek terhadap ekonomi $(18,2 \%)$, dan tidak dapat beraktivitas normal (18,9\%). Sedangkan dampak positif yang dirasakan sebagian besar menyatakan bahwa hal

\section{9 | Psychophedia Jurnal Psikologi Universitas Buana Perjuangan Karawang}


tersebut membuat mereka bisa berkumpul dengan keluarga (40,2\%).

\section{Kepustakaan}

Abdollahi, A., Carlbring, P., Khanbani, M., \& Ghafarokhi, S. A. (2016). Emotional intelligence moderates perceived stress and suicidal ideation among depressed adolescent inpatients. Personality and Individual Differences, 223-228.

Maciejewski, D., Lauharatanahirun, N., Herd, T., Lee, J., Deater-Deckerd, K., King-Casas, B., \& Kim-Spoon, J. (2017). Neural cognitive control moderates the association between insular risk processing and risk-taking behaviors via perceived stress in adolescents. Developmental Cognitive Neuroscience.

Manzar, M. D., Salahuddin, M., Alghadir, A., Anwer, S., Bahammam, A. S., \& Pandi-Perumal, S. R. (2018). Psychometric properties of the perceived stress scale in Ethiopian
University Students. BMC Public Health.

Mimura, C., \& Griffiths, P. (2008). A Japanese version of the perceived stress scale: Cross cultural translation and equivalence assessment. $B M C$ Psychiatry.

Murray, K. M., Byrne, D. G., \& Rieger, E. (2011). Investigating adolescent stess and body image. Journal of Adolescence, 269-278.

Papalia, D. E. (2007). Human development $10^{\text {th }} \mathrm{Ed}$. New-York: McGraw-Hill.

Putri, G. S. (2020, March 12). kompas.com. Retrieved from https://www.kompas.com/sains/read/ 2020/03/12/083129823/who-resmisebut-virus-corona-covid-19sebagai-pandemi-global?page=all.: https:/www.kompas.com/sains/read/ 2020/03/12/083129823/who-resmisebut-virus-corona-covid-19sebagai-pandemi-global?page $=$ all.

Santrock, J. W. (2008). Educational psychology. Boston: Mc-Graw Hill. 